Works of the Faculty of Forestry

University of Sarajevo

No. 1, 2019 (88-103)

UDK $630 * 232: 582.475(497.6)$

\title{
THE EFFECT OF MECHANICAL BARK DAMAGE ON THE VOLUME INCREMENT OF TREES
}

\section{Uticaj mehaničkih oštećenja kore na zapreminski prirast stabala}

\author{
A. Lojo $^{1}$, J. Musić ${ }^{1}$
}

\section{Abstract}

It is well known that mechanical damage to trees, caused by felling and removal of timber from the forest, has multiple negative effects on the quality of the stock and the health of the forests as well as the volume increment. In Bosnia and Herzegovina there were no significant analises of volume increment loss due to bark damage of the trees. In this paper, a direct relationship between the significant damage to the bark of the stem and the size of the volume increment of individual trees was determined. Original data recorded during the Second National Forest Inventory in Bosnia and Herzegovina (2006-2009), within the accesible high economical forests was used. These forests cover a total area of 1.329 .500 ha.

Data on measured trees was taken from every fourth sample plot (one from cluster). 18.546 trees were selected, on which the 10-year increment of brest diameter (DBH) was measured and significant mechanical damage was recorded (LOJO et al., 2008). Of the total number of selected trees, 2.635 or $14.21 \%$ were mechanically damaged.

The results of the study showed that the volume increment of trees, with significant bark damage of all tree species and thickness, was lower from $4,9 \%$ to $19,4 \%$ in average, compared to undamaged trees.

Based on registered damage the bark of the stem, during second NFI BiH and determined the average losses increment on individual trees, it was estimated how much these losses are on an annual basis in, productive high forests in Bosnia and Herzegovina.

The volume increment of mechanically damaged trees is statistically significantly lower compare to the increment of undamaged trees, resulting in a total loss of about 200.000 $\mathrm{m}^{3} /$ year / 1.329.500 ha.

Key words: Mechanical tree bark damage, tree volume increment

\section{INTRODUCTION- Uvod}

Efforts to increase labor productivity, reduce unit costs, and facilitate extremely difficult and demanding forestry work have resulted in a significant mechanization of forest operations in the 1960s. To this end, the development of the management system is also directed, especially in the part of the internal spatial planning of stands, which

\footnotetext{
${ }^{1}$ Faculty of Forestry University of Sarajevo, Zagrebačka 20, 71000 Sarajevo, Bosnia and Herzegovina
} 
primarily aims at creating the preconditions for the use of mechanization and mechanized means in carrying out work operations of forest utilization with as little damage as possible.

However, it quickly became clear that every application of machinery in the forest, certainly has certain negative consequences for the forest ecosystem (emission of harmful substances, extinguishing and compresssion of soil, damage to the young and older standing trees, etc.). The negative impacts of machinery on the forest ecosystem have been the subject of ongoing and numerous studies with often different results and thus conclusions regarding the measures necessary to reduce them. This is first and foremost conditioned by different research methodologies, but also by the significant heterogeneity of the means and techniques of work, field and stand conditions, the manner of forests care and restoration, management systems, etc. Among the numerous authors dealing with forest damage, there is general agreement that, due to the nature of the work, forest operations cannot be carried out without some damage to the forest ecosystem, despite the protection measures implemented.

Also, most researchers believe that the number of mechanically damaged trees is a good indicator of overall damage to the stand (TOMANIĆ et al. 1989; REISINGER and POPE 1991; ATHANASSIADIS, 1997; SIRÉN, 2001). These damages can be determined relatively easily and accurately, and their environmental and economic consequences (decline in value, decrease in growth, tree dieback) are better known than those caused by damage to the young trees or soil (MARTINIĆ, 2000).

\section{PROBLEMATIC ISSUES AND GOAL OF WORK - Problematika rada i cilj rada}

The significant heterogeneity level of of trees in our forests, in terms of quality and technical usability, necessitated the development and binding application of quality classification of trees (MATIĆ et al., 1971; MUSIĆ and LOJO, 2006), with a greater number of different parameters being evaluated and / or measured on the tree. For the evaluation of trees in terms of their quality and health status and monitoring changes in this regard, a relatively small number of quality classes is sufficient, so that the silvicultural-technical classification of trees is divided into three quality classes, with the criteria defined for classes I and III.

The first (I) class thus includes healthy, normally formed trees of good quality, which are potentially able to provide logs of excellent or good quality, or there are chances that it will be possible when the tree grows up.

In class III, trees are generally classified as the ones that do not supposed to be in a commercial forest. These are badly injured, diseased, rotten trees or healthy trees whose stems can only be used for firewood and pulpwood due to quality defects. All other trees that do belong in either of these classes (I and III) are classified as trees of second (II) quality class.

Due to the need to plan forestry production and use, or to carry out cultivation operations, the classification criteria are defined according to certain thickness classes 
and tolerate the corresponding quality errors whereby these tolerances increase with the increase in the breast diameter $(\mathrm{DBH})$ of the tree.

Mechanical damage is one of the essential parameters for the assessment of the quality of trees and for the subsequent analysis of the quality of forest management as well as for the evaluation of the effects of applied forest utilization technologies. When recording mechanical damage, only significant damage is recorded, that is, those that reduce the quality of trees in silvicultural view and classify them as second or third quality class, depending on the width (size) of the stem and/or tree canopy injury. In addition, damage is also recorded by its location and the cause of it.

Mechanical damage is considered to be a tree stem injury incidentally caused by a means of work, or some other biotic and abiotic factors. Most of these are usually a collateral damage that happens during the execution of forestry operations, and their type, size and severity depend on the following factors:

- framework factors (slope of terrain, distance between upright trees, intensity and types of felling, dimensions of trees and assortments, canopy size, season of operation, etc.),

- working methods and techniques,

- spatial plan of the harvesting area (cutting system),

- human factor (skills and motivation).

The magnitude of the impact of these factors is precisely proportional to their orderin which they were listed priorly. This practically means that with adequate motivation of trained workers, a good spatial plan of logging and the application of working methods and techniques in accordance with the field and stand conditions, negative consequences can be reduced to a minimum or "acceptable" level.

Mechanical damage to trees is most commonly classified according to the site of occurrence of the tree (Figure 1) and the degree of damage (Figure 2), with most authors using the MENG, (1978) classification. 


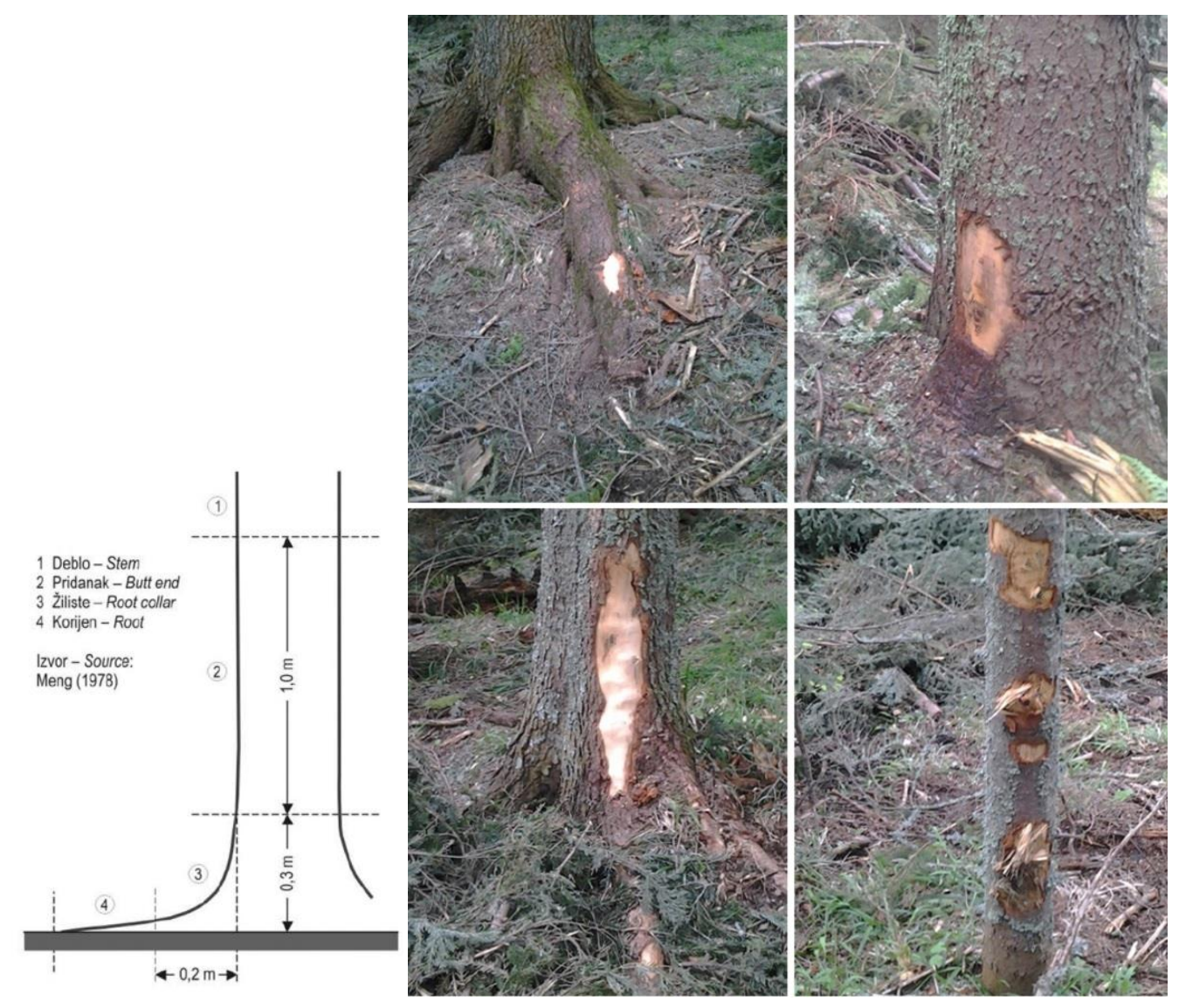

Figure 1. Classification and representation of tree damage position

Slika 1. Klasifikacija i prikaz mjesta oštećenja stabla

The location and extent of the damage depend on the work technologies used, the type and dimensions of the tree, the season of work and other influencing factors. For example, according to a study by SOLGI and NAJAFI (2007) in beech and hornbeam forests in Iran, while pulling a tree with a skidder, the most common damage appears on the roots of the remaining trees, taking up $41 \%$ of the total damage.On the other hand, TSORIAS and LIAMAS (2010), investigating mechanical damage in mixed beech and oak forests when pulling logs with an adapted agricultural tractor, registered the most damage on the stems of the trees, while KNEŽEVIĆ et al. (2018) registered the most damage on base of the trunk and root collar when pulling logs by oxen. It is important to emphasize that any injury to a tree does not a priori mean itsimpairment. 

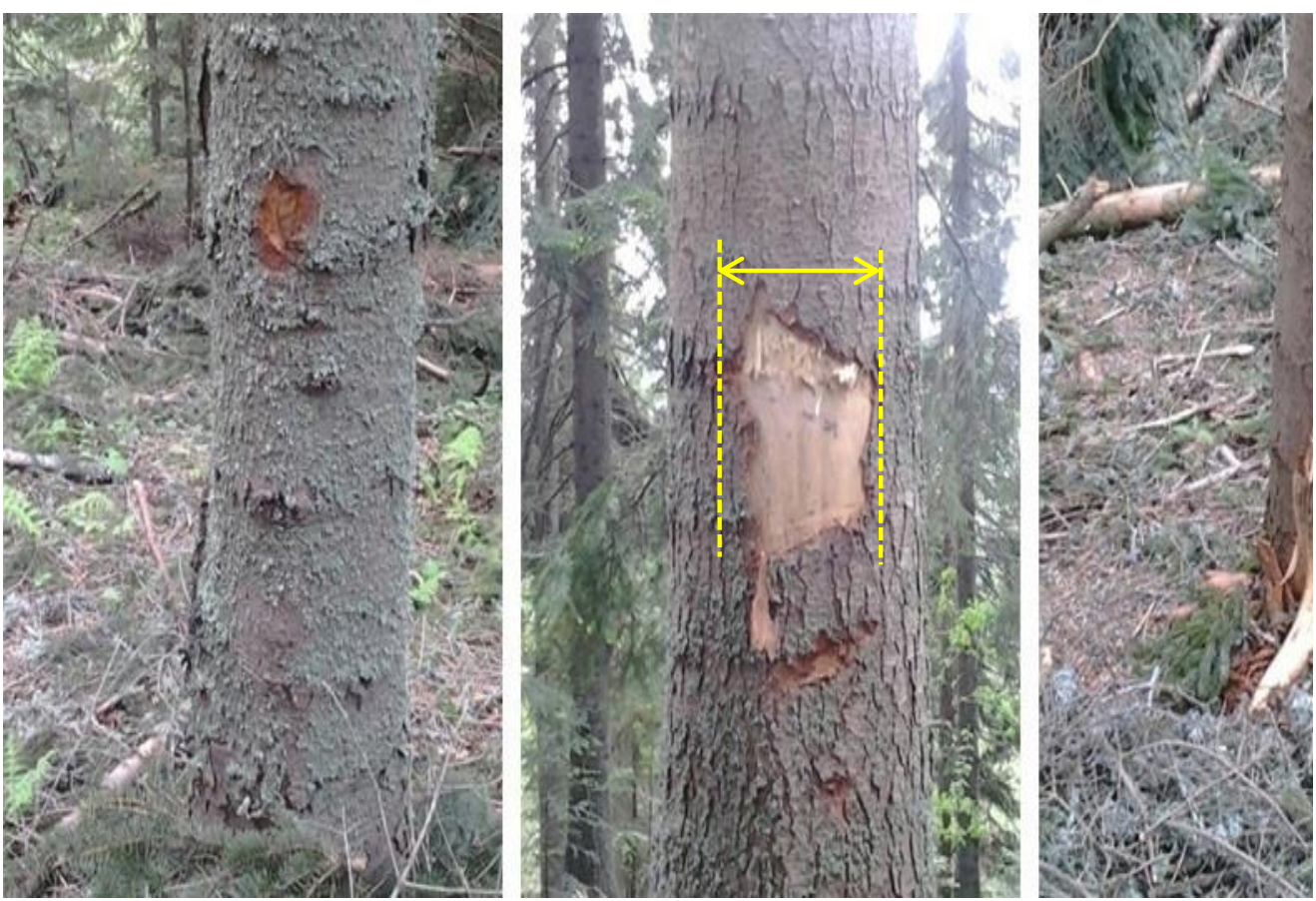

I) Squashed bark
I) Nagnječena kora
II) Debarked tree with relevant width of damage for classification (MATIĆ et al., 1971)

II) Oguljena kora sa relevantnom širinom za klasifikaciju (MATIĆ i dr., 1971)

Figure 2. Classification of trees according to the degree of damage Slika 2. Klasifikacija stabala prema stepenu oštećenja

The appearance of decaying fungi and their development depend on the size and age of the injury, the type of tree, the time and place of injury (VASILIAUSKAS, 2001). The possibility of infection being less in the case of the squashed relative to the peeled bark of the tree (LIMBECK-LILIENAU, 2003), while BETTINGER and KELLOG (1993) find that trees with stem bark injuries closer to ground level are more likely to develop mycosis of tree destroyers. Although the literature does not specify which area or size of the injury has an impact and with what consequences on the damaged tree (PORŠINSKY and OŽURA, 2006), there are certain findings, of which the most relevant to us are those related to the local climatic and vegetation conditions.

So MATIĆ et al. (1971), in the silvicultural-technical classification of trees, of our most important tree species, specify the injury width of $10 \mathrm{~cm}$ as critical, that is, which classifies beech, fir and spruce trees in III silvicultural-technical quality class 
(Figure 2-II). For pines slightly larger injuries are allowed and range from 10 to $20 \mathrm{~cm}$, depending on the type and breast diameter. KRPAN et al., (1993) state that tree infestation and rot development depend on the size of the injury and its position on the stem. Mycosis development has not been established on injuries below $100 \mathrm{~cm}^{2}$, so they believe that the tree can heal such injury.

In addition to the real possibility of infestation of damaged trees with rotting fungi and their subsequent decay, and the established degradation of the quality of cut and damaged trees (VANDERBERG, 2002), the negative impact of mechanical damage on the volume increment of standing trees is also very significant. ISOMÄKI and KALLIO (1974) state that root damage reduced spruce diameter increment by $35 \%$ and height increment by $25 \%$, and stem damage reduced these increments by $15 \%$. In doing so, the width and depth of injuries correlate positively with the decrease in increment. TAVANKAR et al., (2015) found a $8.1 \%$ decrease in the diameter incrementof damaged beech trees, citing as significant factors the decrease in the growth of damaged trees: distance of damage from the soil, area of injury and age of the tree. Analyzing the width of the year-rings of damaged pedunculate oak and beech trees KRPAN et al. (1993) found a volume incrementloss of 1 to $4.7 \%$. According to research by REBULA, (1991), about $15 \%$ of trees are damaged in Slovenia due to the construction of tractor roads and tree pulling. $1 / 3$ of damaged trees do great damage, which diminishes their use value and reduces diameter increment.A number of studies have also shown that damage to the spruce stem results in a 14-25\% reduction in increment (BAADER, 1956; VANEK, 1957). In contrast, a number of authors have not identified a significant effect of stem injury on the reduction of spruce increment (STAINES and WELCH, 1984), spruce and white pine (MÄKINEN et al., 2007) and oak (VASILIAUSKAS, 1998).

The main motives of this paper, which aim to determine the degree of mechanical damage to the trees and their effect on the volume increment, arise from the explained problems.

\section{MATERIAL AND METHODS OF WORK - Materijal i metod rada}

The basic material for this work is the data on mechanical damage and $\mathrm{DBH}^{1}$ breast height diameter increment of trees, collected by inventory recordings during the implementation of the Second National Forest Inventory in BiH (NFI) from 2006 to 2009.

Specifically, for the needs of NFIs, a number of taxation elements, including mechanical damage of the trees, according to their location (stem or canopy) and the extent of damage, were recorded on every fourth sample plot (LOJO et al., 2008). Recorded tree data from sample plots within all "available high production character forests" were extracted from the formed database.

According to the NFI data processed, the total area of these forests in $\mathrm{BiH}$ was

${ }^{1}$ Diameter of the tree at the breast height

Prečnik stabla na prsnoj visini 
$1,329,500$ ha. Of these, $1,063,400$ ha $(79.98 \%)$ are state forests and 266,100 ha are private $(20.02 \%)$. The volume increment of large wood ${ }^{1}$ of these forests and its structure by groups of tree species is shown in Table 1 .

Table 1: Volume increment ${ }^{1}$ (by groups of tree species) of high economic forests in $\mathrm{BiH}$ according to second NFI (2006-2009)

Tabela 1: Zapreminskog prirasta krupnog drveta (po grupama vrstama drveća) visokih šuma proizvodnog karaktera u BiH prema drugoj NFI (2006.-2009.)

\begin{tabular}{|c|c|c|c|c|}
\hline \multirow{2}{*}{$\begin{array}{c}\text { Area } \\
\text { Površina } \\
\text { (ha) }\end{array}$} & \multirow[t]{2}{*}{$\begin{array}{c}\text { Groups of tree species } \\
\text { Grupe vrsta drveća }\end{array}$} & \multicolumn{2}{|c|}{$\begin{array}{c}\text { Volume increment }{ }^{1} \\
\text { Zapreminski } \\
\text { prirast }\end{array}$} & \multirow{2}{*}{$\begin{array}{c}\text { Share in } \\
\text { increment } \\
\text { Udio u prirastu } \\
(\%)\end{array}$} \\
\hline & & (m³/god.) & $\left(\mathrm{m}^{3} / \mathrm{ha}\right)$ & \\
\hline \multirow{3}{*}{1.329 .500} & Coniferous - Četinari & 4.149 .465 & 3,1 & 45,8 \\
\hline & Broadlaves - deciduous__Lišćari & 4.920 .196 & 3,7 & 54,2 \\
\hline & All species - Sve vrste & 9.069 .660 & 6,8 & 100,0 \\
\hline
\end{tabular}

The recorded significant mechanical bark damage to trees on the sample plots is classified as follows:

0 - undamaged tree;

1 - mechanically damaged tree (criterion - II silvicultural-technical class);

2 - mechanical damage to the tree (criterion - III silvicultural-technical class). „Statgraphics Centurion" computer software was used for statistical data processing and interpretation of results. The verification of the normality of the original data (distribution analysis) and their transformation were prepeared by the Box-Cox procedure (BOX and COX, 1964).

\section{RESULTS AND DISCUSSIONS - Rezultati rada i diskusija}

Based on data from 2.319 sample plots and 18.545 measured trees, average size of annual DBH increment and average size of annual volume increment of trees in total wood mass ${ }^{2}$ were calculated, and the number of mechanically damaged trees per degree of bark damage was determined (Table 2).

\footnotetext{
${ }^{1}$ Volume increment of tree sections thicker than $7 \mathrm{~cm}$ Zapreminski prirast dijelova stabla debljih od $7 \mathrm{~cm}$
} 
Table 2: Average size of annual diameter (DBH) and volume increment of one tree and the number and proportion of damaged trees by degree of bark damage (source NFI$\mathrm{BiH})$

Tabela 2: Prosječne veličine godišnjeg debljinskog i zapreminskog prirasta ${ }^{1}$ jednog stabla te broj i udio oštećenih stabala po stepenu oštećenja kore (izvor NFI-BiH)

\begin{tabular}{|c|c|c|c|c|c|}
\hline $\begin{array}{l}\text { Bark } \\
\text { damage- } \\
\text { type } \\
\text { Oštećenje } \\
\text { kore - }\end{array}$ & $\begin{array}{c}\text { Tree } \\
\text { number } \\
\text { Broj } \\
\text { stabala }\end{array}$ & $\begin{array}{l}\text { Average brest } \\
\text { tree diameter } \\
\text { (DBH) } \\
\text { Prosječan } \\
\text { prsni prečnik } \\
\text { stabla }\end{array}$ & $\begin{array}{c}\text { Percentage } \\
\text { share } \\
\text { Procentualni } \\
\text { udio }\end{array}$ & $\begin{array}{c}\text { Average } \\
\text { diameter } \\
(\mathrm{DBH}) \\
\text { increment } \\
\text { Prirast } \\
\text { prečnika } \\
\text { stabla } \\
\end{array}$ & $\begin{array}{c}\text { Volume } \\
\text { increment of } \\
\text { the tree } \\
\text { Zapreminski } \\
\text { prirast stabla }\end{array}$ \\
\hline & & $(\mathrm{cm})$ & $(\%)$ & (mm/god.) & ( $\mathrm{m}^{3} /$ god.) \\
\hline 0 & 15.911 & 31,7 & 85,79 & 3,63839 & 0,0294139 \\
\hline 1 & 1.445 & 38,0 & 7,79 & 3,53135 & 0,0355895 \\
\hline 2 & 1.190 & 38,8 & 6,42 & 3,18874 & 0,0318412 \\
\hline $\begin{array}{l}\text { Total - } \\
\text { Ukupno }\end{array}$ & 18.546 & 32,6 & 100,00 & 3,60120 & 0,0300509 \\
\hline
\end{tabular}

Higher diameter increment and smaller volume increment of undamaged trees (table 2) is conditioned by the structure of the tree sample per DBH.

Namely, there are many more damaged trees in the higher diameter classes ( 1.636 or $16,8 \%$ in diameter above $30 \mathrm{~cm}$ ) than in the lower ones $(1.035$ or $11,7 \%$ in diameter below $30 \mathrm{~cm}$ ). On average, thicker trees and smaller diameter increments have larger volume increment due to the greater height and basal area (or incremental rings area).

Of the total number of trees, 2.635 or $14,21 \%$ were mechanically damaged. Considering that these are only significant damages, we can conclude that this is an extremely large proportion. Comparatively, in extensive studies of tree damage during felling, fabrication and hauling logs, MARTINIĆ, (1991) found a total damage rate of $8,2 \%$, indicating that the most frequent damage was squashed and peeled bark. That the level of forest damage in $\mathrm{BiH}$ is far higher is confirmed by the results of ZAHIROVIĆ et al. (2016) who, in their research, determined an overall damage of $35.1 \%$, with root and trunk damage the most common (71.6\%) and HALILOVIĆ et al. (2020) who determined overall damage of $30.6 \%$ in their research.

Determining the statistical significance of the effect of mechanical damage on the volume increment of trees was performed by multivariate analysis of variance. Prior to analysis, the normality of the volume increment value distribution was checked by

\footnotetext{
${ }^{1}$ Volume increment of trees of total wood mass (without stump) Zapreminski prirast ukupne drvne mase stabala (bez panja)
} 
Box-Cox procedure (BOX and Cox 1964). The distribution of the original data (Iv) was found to deviate from the normal, so an exponent of 0.2 was determined for their optimal transformation to the normal distribution $\left(\mathrm{Iv}^{0,2}\right)$.

The independent categorical variables that were taken into account are: damage type ("Bark damage") and group of tree species ("Group sp."), with trees being classified into conifer and broadleaves species groups.

To exclude the stated influence on volume increment, DBHwas included as a covariate. Due to needed normality of the DBH data value, transformation with appropriate exponent of 0,5 was applied. The result of the multifactorial analysis of the variance of the volume increment of the trees is shown in Table 3.

Table 3. Analysis of Variance forIv $v^{0,2}$

Tabela 3: Analiza varijanse za Iv $v^{0,2}$

\begin{tabular}{|c|c|c|c|c|c|}
\hline $\begin{array}{l}\text { The source of variation } \\
\text { Izvor variranja }\end{array}$ & $\begin{array}{c}\text { Sum of } \\
\text { squares } \\
\text { Suma } \\
\text { kvadrata } \\
\end{array}$ & $\begin{array}{c}\text { Degrees of } \\
\text { freedom } \\
\text { Stepeni } \\
\text { slobode }\end{array}$ & $\begin{array}{c}\text { Mean } \\
\text { SquareSredina } \\
\text { kvarata }\end{array}$ & $\begin{array}{l}\text { F- ratio } \\
F-\text { odnos }\end{array}$ & $\begin{array}{c}\text { "P" } \\
\text { probability } \\
\text { "P" } \\
\text { vjerovatnoća }\end{array}$ \\
\hline \multicolumn{6}{|l|}{ Covariate-Kovarijabla } \\
\hline $\mathrm{DBH}^{0,5}$ & 184,252 & 1 & 184,252 & 71428,75 & 0,0000 \\
\hline \multicolumn{6}{|c|}{ Main effects - Kategorijske varijable } \\
\hline \begin{tabular}{|l} 
A: Group sp. - \\
Grupa vrsta \\
\end{tabular} & 1,72505 & 1 & 1,72505 & 668,75 & 0,0000 \\
\hline $\begin{array}{l}\text { B: Bark damage } \\
\text { Oštećenje }\end{array}$ & 0,519276 & 2 & 0,259638 & 100,65 & 0,0000 \\
\hline $\begin{array}{l}\text { Residual } \\
\text { Rezidual }\end{array}$ & 47,8244 & 18540 & 0,00257952 & & \\
\hline $\begin{array}{l}\text { Total (corrected) } \\
\text { Ukupno }\end{array}$ & 236,306 & 18544 & & & \\
\hline
\end{tabular}

According to the variance ratio (F-ratio) and error probability (P-value), it is clear that all the analyzed factors have a statistically significant effect on the tree's volume increment. Nevertheless, starting from the research objective, an analysis of the effect of mechanical damage type on the volume increment of trees was performed, and the results are presented in Chart 1 and Table 4 


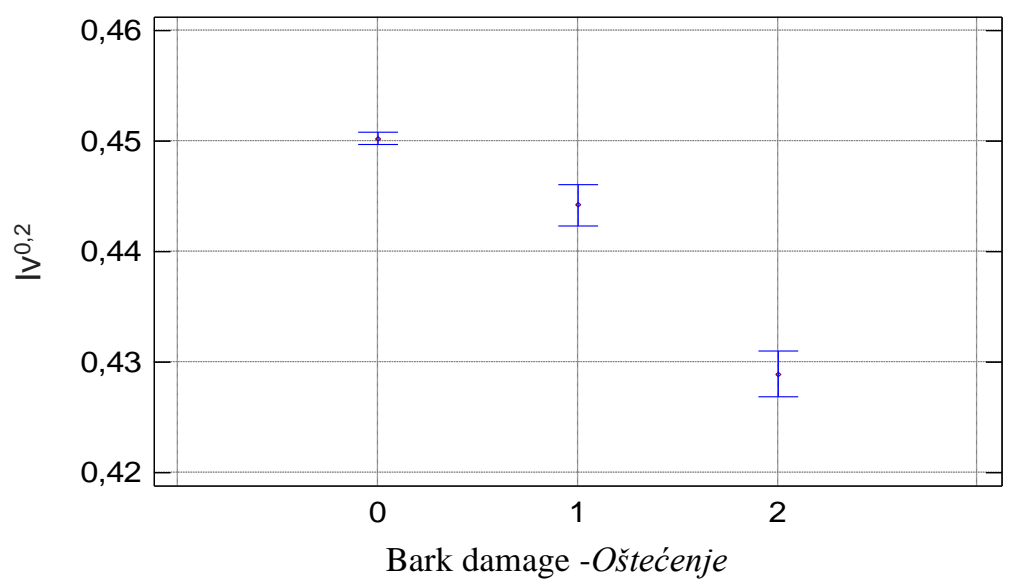

Graph 1. Average values of Iv ${ }^{0,2}$ and Fisher's LSD intervalper type of damage, $95 \%$ probability Grafikon 1. Prosječne veličine Iv $v^{0,2} i$ Fisherov LSD interval po tipovima oštećenja, pri vjerovatnoći od $95 \%$

Table 4.Multiple Range Tests for $\mathrm{Iv}^{0,2}$ ) by „Oštećenje“ (LSD -the least significant difference Fisher test, $95 \%$ probability )

Tabela 4: Višestruki rang test za prosječne veličineIv ${ }^{0,2}$, najmanja značajna razlika (LSD Fisher test) i formirane homogene grupe uz vjerovatnoću $95 \%$

\begin{tabular}{|c|c|c|c|c|c|c|}
\hline Bark & Count & \multirow{2}{*}{$\begin{array}{c}\text { LS Mean } \\
\text { damage - }\end{array}$} & $\begin{array}{c}\text { Broj } \\
\text { Oštećenje }\end{array}$ & $\begin{array}{c}\text { Srednja veličina } \\
\text { zapreminskog } \\
\text { prirasta }^{1}\end{array}$ & $\begin{array}{c}\text { LS Sigma } \\
\text { Značajna } \\
\text { razlika }\end{array}$ & \multicolumn{3}{|c|}{$\begin{array}{c}\text { Homogeneous Groups } \\
\text { Homogene grupe }\end{array}$} \\
\cline { 6 - 8 } & 1190 & 0,428922 & 0,00148837 & $\mathrm{X}$ & 2 & 3 \\
\hline 2 & 1445 & 0,444234 & 0,00134368 & & $\mathrm{X}$ & \\
\hline 1 & 15911 & 0,450248 & 0,000403914 & & & $\mathrm{X}$ \\
\hline 0 & &
\end{tabular}

Graph 1 and Table 4 show average tranformed value $\left(\mathrm{Iv}^{0,2}\right)$ of the tree volume incrementand least significant differences (LSD interval) at $95 \%$ probability per bark damage degree. It is observed that $\mathrm{Iv}^{0,2}$ is the highest in undamaged trees and decreases towards trees with greater mechanical damage. The test showed that the differences in the volume increment between all groups formed (by type of damage) were statistically significant (Table 5). 
Table 5. Multiple Range Test comparison of means ( $\left.\mathrm{Iv}^{0,2}\right)$ by type of damage Tabela 5. Multipli Rang Testpoređenje sredina $\left(I v^{0,2}\right)$ po tipu oštećenja

\begin{tabular}{|c|c|c|c|}
\hline $\begin{array}{c}\text { Contrast } \\
\text { Poređenje }\end{array}$ & $\begin{array}{c}\text { Significance } \\
\text { Značajnost }\end{array}$ & $\begin{array}{c}\text { Difference } \\
\text { Razlike }\end{array}$ & $\begin{array}{c}\text { +/-Limits } \\
\text { +/-Limiti }\end{array}$ \\
\hline $0-1$ & $*$ & 0,0060140 & 0,00250496 \\
\hline $0-2$ & $*$ & 0,0213257 & 0,00409521 \\
\hline $1-2$ & $*$ & 0,0153116 & 0,00214048 \\
\hline
\end{tabular}

* denotes a statistically significant difference.

* označava statistički značajnu razliku

The confirmation of the correctness of the performed analysis is clearly evident from the graph 2, which shows the distribution of residuals of estimated size $\left(\operatorname{Iv}^{0,2}\right)$ around the categories of the independent variable ("Bark damage"). It can be seen that the positive and negative values of the residuals are equally distributed around the estimated value of the $\mathrm{Iv}^{0,2}$.

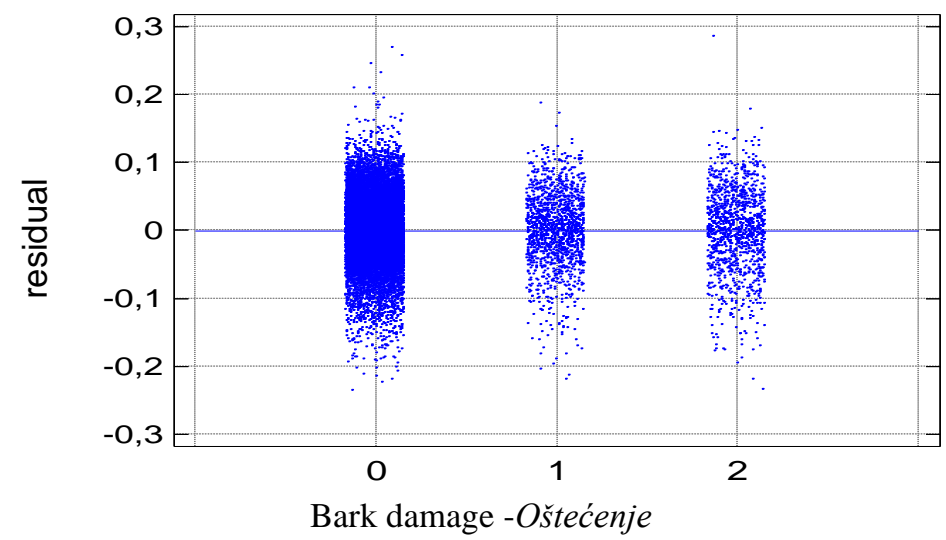

Chart 2. Distribution of residuals estimated value of $\mathrm{Iv}^{0.2}$ per independent variable categories (,Bark damage“)

Grafikon 2. Raspored reziduala procijenjene veličine $I v^{0,2}$ po kategorijama nezavisne varijable (,Oštećenje“)

Based on the obtained results, we can conclude that the mean volume increment of undamaged trees is $1.35 \%$ higher than trees with less mechanical damage (type 1) and $4.97 \%$ compared to trees with more mechanical damage (type 2). The results obtained are highly correlated with the results obtained by KRPAN et al. (1993). They found a loss in volume increment of mechanically damaged trees from 1 to $4.7 \%$. This is especially important as these are studies in areas where the same forest utilization technologies are applied with approximately similar length of vegetation period. 
The obtained data on the mean volume increment of one tree and the average number of trees per sample plot were used to calculate the average annual volume increment per hectare of forest area and its percentage reduction due to mechanical damage. The results are shown in Table 6.

Table 6. Decrease in volume increment of damaged trees, calculated on 1 ha of high forests in B\&H Tabela 6. Smanjenje zapreminskog prirasta ${ }^{3}$ oštećenih stabala preračunato na 1 ha visokih šuma u $\mathrm{BiH}$

\begin{tabular}{|c|c|c|c|c|c|}
\hline \multirow[t]{2}{*}{$\begin{array}{c}\text { Bark } \\
\text { damage - } \\
\text { Ošté́enje }\end{array}$} & \multirow[t]{2}{*}{$\begin{array}{l}\text { Tree } \\
\text { number } \\
\text { Broj } \\
\text { stabala }\end{array}$} & $\begin{array}{l}\text { Average volume } \\
\text { increment of one } \\
\text { tree }^{3} \\
\text { Prosječan } \\
\text { zapreminski prirast } \\
\text { jednog stabla }{ }^{3}\end{array}$ & \multirow[t]{2}{*}{$\begin{array}{c}\text { Average number } \\
\text { of trees per plot } \\
\text { Prosječan broj } \\
\text { stabala na jednoj } \\
\text { plohi }\end{array}$} & $\begin{array}{l}\text { Average volume } \\
\text { increment }^{3} \\
\text { Prosječan } \\
\text { zapreminski prirast }^{1}\end{array}$ & $\begin{array}{c}\text { Increme } \\
\mathrm{nt} \\
\text { reductio } \\
\mathrm{n} \\
\text { Umanje } \\
\text { nje } \\
\text { prirasta }\end{array}$ \\
\hline & & $\begin{array}{l}\mathrm{m}^{3} / \mathrm{ha} / \text { tree/year. } \\
\mathrm{m}^{3} / \mathrm{ha} / \text { stablo/god. }\end{array}$ & & $\begin{array}{l}\mathrm{m}^{3} / \mathrm{ha} / \text { year. } \\
m^{3} / \mathrm{ha} / \text { god } \text {. }\end{array}$ & $\%$ \\
\hline 0 & 15911 & 1,18956 & \multirow{3}{*}{7,997413} & 9,5 & 0,00 \\
\hline 1 & 1445 & 1,13108 & & 9,0 & 4,92 \\
\hline 2 & 1190 & 0,959044 & & 7,7 & 19,38 \\
\hline
\end{tabular}

The average reduction in volume increment is from 0,5 to $1,8 \mathrm{~m}^{3}$ / ha / year, which for a ten-year period amounts to $5-18 \mathrm{~m}^{3}$ per hectare of area, assuming the stands of only damaged or undamaged trees.

By comparison, KARDEL, (1978) found a loss of growth in spruce stands due to damage from hauling trees by tractors, from 5 to $15 \mathrm{~m}^{3}$ in the same period (10 years). If the data on average volume increments determined on the sample plots and calculated on 1 ha (Table 6) are calculated on the total area of high forests in $\mathrm{BiH}(1,329,500 \mathrm{ha})$, we obtain data on the total volume increments. Based on the share of barke damaged trees (type 1 and 2) in the total number of trees, a total annual loss in volume increment of $205,713 \mathrm{~m}^{3} /$ year was calculated, only due to mechanical damage to the trunks of trees.

\section{CONCLUSIONS - Zaključci}

- Mechanical damage to trees has multiple negative impacts, which is reflected in the reduction of vitality, productivity and value of trees as well as other components of the forest ecosystem. However, this very important and complex problem in BiH's forestry practice and science, has unfortunately not received adequate attention.

- The share of damaged trees with significant decrease in quality and their value in $\mathrm{BiH}$ forests is high $14,21 \%$.

\footnotetext{
${ }^{1}$ Zapreminski prirast ukupne drvne mase stabala (bez panja)

Volume increment of trees of total wood mass (without stump)
} 
- The volume increase of mechanically damaged trees is statistically significantly lower than that of non-damaged trees resulting in a total loss of about 200,000 $\mathrm{m}^{3} /$ year. which at the current average prices of wood assortments represents a financial loss, only on the basis of volume increment, of about 18 mil. BAM.

- Mechanical damage to trees is an unavoidable risk when applying prescribed management systems and applied forest harvesting technologies. However, it is necessary and cost-effective to take all possible measures that would result in their reduction and increase in the volume increment, quality and value of the trees in the future.

\section{REFERENCES - Literatura}

ATHANASSIADIS, D. (1997): Residual stand damage following cut-to-length harvesting operations with a farm tractor in two conifer stands. Silva Fennica 31(4): 461- 467.

BAADER, G. (1956): Damage by game in Rheinland-Pfalz and the possibilities to minimize it. Allgemine Forest Jagdztg 127: 233-240.

BETTINGER, P., KELLOGG, L.D. (1993): Residual stand damage from cut-tolength thinning of second-growth timber in the Cascade Range of western Oregon. Forest Product Journal 43: 59-64.

BOX, G.E.P., COX, D.R. (1964): An Analysis of Transformations. Journal of the Royal Statistical Society, Series B (Methodological) 26 (2):211-252.

ISOMÄKI, A., KALLIO, T. (1974): Consequences of injury caused by timber harvesting machines on the growth and decay of spruce (Picea abies (L) Karst.) Acta Forestalia Fennica 136: 1-25.

HALILOVIĆ, V., MUSIĆ, J., KNEŽEVIĆ, J., ŠARIĆ, M., BALIĆ, B., BALLIAN, D. (2020): Research of mechanical damage of fir trees and other trees species during exploitation - Case Forestry „Glamoč“. Šumarski list 3-4, pp 149-158.

KARDELL, L. (1978): Damage caused by tractors and losses in tree growth - an analysis of 10-year long study. Svenska Skogsvårdsföreningens Tidskrift76:305322.

KNEŽEVIĆ, J., GURDA, S., MUSIĆ, J., HALILOVIĆ, V., SOKOLOVIĆ, DŽ., BAJRIĆ, M. (2018): The Impact of Animal Logging on Residual Trees in Mixed Fir and Spruce Stands. South-east European Forestry 9 (2): 107-114.

KRPAN, A. P. B., PETREŠ, S., IVANOVIĆ, Ž.(1993): Neke fizičke štete u sastojini, posljedice i zaštita. Glasnik za šumske pokuse, Posebno izdanje 4: 271-279.

LIMBECK-LILIENAU, B. (2003): Residual stand damage caused by mechanized harvesting systems. In: Proceedings of the Austro2003 meeting: High Tech Forest Operations for Mountainous Terrain. CD ROM. Limbeck-Lilienau, Steinmüller and Stampfer (editors). October 5-9, 2003, Schlaegl - Austria. 11 p. 
LOJO A., BALIĆ B., MEKIĆ F., BEUS V., KOPRIVICA M., TREŠTIĆ T., MUSIĆ J. ČABARAVDIĆ A., HOČEVAR M. (2008): Metodika druge inventure šuma na velikim površinama u Bosni i Hercegovini. Radovi Šumarskog fakulteta Univerziteta u Sarajevu, Posebna izdanja br. 20 (1):1-156.

MÄKINEN,H., HALLAKSELA,A-M., ISOMÄKI, A. (2007): Increment and decay in Norway spruce and Scots pine after artificial logging damage. Canadian Journal of Forest Research37(11): 2130-2141.

MARTINIĆ , I.(1991): Oštećenje sastojine pri obaranju stabala, izradi i privlačenju drva. Šumarski list 1-2:33-47.

MARTINIĆ, I. (2000): Koliko smo blizu ekološki prihvatljivoj uporabi mehanizacije u šumarstvu? Šumarski list 1-2:3-13.

MATIĆ, V., DRINIĆ, P., STEFANOVIĆ, V., ĆIRIĆ, M., BEUS, V., BOZALO, G., GOLIĆ, S., HAMZIĆ,U., MARKOVIĆ, LJ., PETROVIĆ, M., SUBOTIĆ, M., TALOVIĆ, N., TRAVAR, J. (1971): Stanje šuma u Bosni i Hercegovini prema inventuri šuma na velikim površinama u 1964-1968. godini. Šumarski fakultet $i$ Institut za šumarstvo u Sarajevu, Posebna izdanja broj 7: 1-639.

MENG, W. (1978): Baumverletzungen durch Transportvorgänge bei der Holzernte - Ausmaß und Verteilung, Folgeschäden am Holz und Versuch ihrer Bewertung. Schriftenreihe der LFV Baden-Württemberg, Band 53: 159 p.

MUSIĆ, J., LOJO, A. (2006): Kvalitetna klasifikacija stabala (Matić i dr., 1971) dopunjena verzija. Knjiga kratkih sadržaja IV Simpozija poljoprivrede, veterinarstva, šumarstva i biotehnologije, 21-23 septembar 2006, Zenica, BiH, str. 130.

PORŠINSKY, T., OŽURA, M. (2006): Oštećivanje dubećih stabala pri izvoženju drva forvarderom. Nova mehanizacija šumarstva 27: 41-49.

REBULA, E. (1991): Posljedice gradnje vlaka u šumi. Mehanizacija šumarstva 16(3): 161-171.

REISINGER, T.W., POPE, P.E. (1991): Impact of timber harvesting on residual trees in a central hardwood forest in Indiana. Proceedings 8th Central Hardwood Forest Conference. University Park, Pennsylvania. March 4-6, 1991.

TOMANIĆ, S., VONDRA, V., MARTINIĆ, I. (1989): Oštećivanje sastojine pri šumskim radovima. Mehanizacija šumarstva $14(3-4)$ : 65-72.

SIRÉN , M. (2001): Tree Damage in Single-Grip Harvester Thinning Operations. Journal of Forest Engineering 12(1): 29-38.

SOLGI, A., NAJAFI, A. (2007): Investigation of residual tree damage during ground-based skidding. Pakistan Journal of Biological Sciences 10: 1755-1758.

STAINES, B.W., WELCH, D. (1984): Habitat selection and impact of red (Cervus elaphus L.) and roe (Capreolus capreolus L.) deer in a Sitka spruce plantation. Proceedings of the Royal Society of Edinburgh 82 (4):303-319. 
TAVANKAR, F., BONYAD, A., MARCHI, E., VENANZI, R., PICCHIO, R. (2015): Effect of logging wounds on diameter growth of beech (Fagus orientalis Lipsky) trees following selection cutting in Caspian forests of Iran. New Zealand Journal of Forestry Science 45:19

TSORIAS, P.A., LIAMAS, D.K. (2010): Hauling damages in a mixed beech oak stand. In: Proceedings of the FORMEC 2010 Forest Engineering: Meeting the Needs of the Society and the Environment, July 11-14, 2010, Padova, Italy. 1/8-8/8.

VANDERBERG, M.R. (2002): Harvested log damage and value loss associated with two ground-based havresting system in Central Appalachia. Master thesis. Davis College of Agriculture, Forestry and Consumer Sciences at West Virginia University, 1-98.

VANEK, J. (1957): Study on the consequences of bark stripping damage caused by game in forest stands. Lesnictvi 3:59-78.

VASILIAUSKAS, R. (1998): Patterns of wounding and decay in stems of Quercus robur due to bark peeling. Scandinavian Journal of Forest Research 13: 437-441.

VASILIAUSKAS R. (2001): Damage to trees due to forestry operations and its pathological significance in temperate forest: a literature review. Forestry $74: 319$ 336.

ZAHIROVIĆ, K., TREŠTIĆ, T., MUJEZINOVIĆ, O., HASKOVIĆ, A. (2016): Utjecaj sječe i izvoza drvne mase na oštećenost i zdravstveno stanje stabala jele i smrče na području planine Zvijezda. Naše šume 44-45: 15-28.

\section{SAŽETAK}

Poznato je da mehanička oštećenja stabala, koja nastaju pri izvođenju sječa i izvlačenju drvne mase iz šume, imaju višestruko negativne posljedice po kvalitet zalihe i zdravstveno stanje šuma kao i zapreminski prirast. U Bosni i Hercegovini značajnih mjerenja gubitaka u veličini zapreminskog prirasta usljed oštećivanja stabala nije bilo. U ovom radu je utvrđivanje uticaja mehaničkih oštećenja na veličinu zapreminskog prirasta stabala postavljeno kao cilj istraživanja. Pri tome su korišteni originalni podaci snimanja provedenog tokom II državne inventure šuma na velikim površinama (NFI) u Bosni i Hercegovini (2006-2009). U obzir su uzete sve dostupne visoke šume proizvodnog karaktera. Ove šume zauzimaju ukupnu površinu od 1.329 .500 ha.Zapreminski prirast krupnog drveta, po grupama vrstama drveća, svih dostupnih visokih šuma proizvodnog karaktera $\mathrm{u} \mathrm{BiH}$, prema snimljenim podacima, prikazan je $\mathrm{u}$ tabeli 1.

Za potrebe ovog istraživanja, iz podataka snimljenih tokom druge NFI, u uzorak je odabrano 18.546 stabala premjernih na detaljnim plohama (svaka četvrta) na kojima je, među ostalim podacima, izmjeren 10-godišnji debljinski prirast stabala i vršena evidencija značajnih mehaničkih oštećenja (LOJO et al., 2008). 
Evidentirana mehanička oštećenja stabala na primjernim plohama razvrstavana su na sljedeće tipove oštećenja:

0 - neoštećeno stablo

1 - mehanički oštećeno stablo (kriterij - II uzgojno-tehnička klasa)

2 - mehaničko oštećeno stablo (kriterij - III uzgojno-tehnička klasa)

$\mathrm{U}$ analizama podataka primjenjena je višefaktorijalna analiza varijanse, gdje su kao nezavisne kategorijske varijable uzete grupe vrsta drveća (četinari i lišćari) i tip mehaničkog oštećenja, da bi se izbjegao jak uticaj prsnog prečnika stabala (DBH) na veličinu zapreminskog prirasta stabla, ovaj faktor (DBH) je uključen kao kovarijabla u analizu. Rezultati su prikazani u tabeli 3 , a značaj pojedinih tipova oštećenja kore debala stabala je prikazan u tabeli 4 i grafikonu 1 ,

Od ukupnog broja stabala njih 2.635 ili 14,21\% je bilo mehanički oštećenih. S obzirom da je riječ samo o značajnim oštećenjima možemo konstatovati da je ovo izuzetno veliki udio.

Utvrđena je direktna zavisnost između značajnih oštećenja kore debla i veličine zapreminskog prirasta pojedinačnih stabala. Zapreminski prirast oštećenih stabala je manji od 4,9 \% (tip 1) do 19.4\% (tip 2), u odnosu na neoštećena stabla (tabela 6).

To rezultira ukupnim gubitkom od oko $200.000 \mathrm{~m}^{3} /$ god. Na ukupnoj površini visokih šuma proizvodnog karaktera u $\mathrm{BiH}$, što pri aktuelnim prosječnim cijenama drvnih sortimenata predstavlja finansijski gubitak, samo po osnovu prirasta, od oko 18 mil. BAM.

Mehanička oštećenja stabala imaju višestruki negativan utjecaj koji se ogleda u smanjenju vitaliteta, poduktivnosti i vrijednosti stabala ali i drugih komponenti šumskog ekosistema. Ipak, ovom veoma bitnom i složenom problemu u bosanskohercegovačkoj šumarskoj praksi i nauci nije, nažalost, posvećena adekvatna pažnja.

Mehanička oštećenja stabala predstavljaju neizbježan rizik pri primjeni propisanih sistema gazdovanja i primjenjivanih tehnologija iskorištavanja šuma. Međutim, neophodno je i isplativo poduzeti sve moguće mjere, koje bi rezultirale njihovim smanjivanjem, te povećanjem prirasta, kvaliteta i vrijednosti stabala u budućnosti.

Corresponding author: Ahmet Lojo, Faculty of Forestry University of Sarajevo; Zagrebačka 20, 71000 Sarajevo, Bosnia and Herzegovina; e-mail address: a.lojo@sfsa.unsa.ba 